Brit. J. industr. Med., 1958, 15, 224.

\title{
SOME OBSERVATIONS ON THE INCIDENCE OF RESPIRATORY CANCER IN NICKEL WORKERS
}

BY

\author{
J. GWYNNE MORGAN
}

From the Mond Nickel Company Ltd., Swansea

(RECEIVED FOR PUBLICATION APRIL 2, 1958)

By far the greater part of all nickel refined in this country is dealt with by the Mond Nickel Company at their Clydach Refinery, near Swansea in South Wales. An inquiry at Clydach works has revealed the following facts: (a) No case of nose cancer has occurred among men who first entered employment there after 1925; $(b)$ the incidence of lung cancer among these same men has been no higher than that in the country as a whole.

The purpose of this paper is to show how these facts have been established. The nature of the process used at Clydach is described, and the history of the investigation of the problem is given.

\section{The Process}

The Clydach Refinery was started in 1902 for the production of nickel by the carbonyl process. During the 55 years it has operated there have been many changes in raw materials, and improvements in the process and equipment.

Nickel ore is mined in Canada. The composition of the ore varies somewhat throughout the ore body but a typical " rich" ore contains about $2.5 \%$ of nickel, $30 \%$ of iron, $25 \%$ of silica, 2 to $4 \%$ of copper, and small amounts of cobalt, selenium, tellurium, silver, and the precious metals.

Preliminary concentrating and refining operations are carried out at the mines, and the material is received at Clydach in the form of a "matte" containing some $80 \%$ metals.

The process adopted at Clydach may be divided into three periods:-

Period 1 (1902-1933). - The raw material contained 40 to $45 \%$ nickel and 35 to $40 \%$ copper. Production of copper sulphate was on a large scale during this period.

Period 2 (1933-1953). - The raw material contained less than $3 \%$ copper. The sulphur content was at first high (over $20 \%$ ) but this was reduced to $7 \%$, and later to about $0.5 \%$. Most of the copper was returned to Canada and very little copper sulphate was made (none for the period 1938-46 inclusive).

Period 3 (1953 to Date).-Raw material contained sinter (3\% copper). A new, " direct wet treatment" process at Clydach replaced the Orford process. All copper was converted to copper sulphate for sale.

Period 1902-1933.-The process consisted essentially of the following:-

(a) The copper-nickel sulphide ores were smelted to a bessemer matte containing approximately $35 \%$ copper, $46 \%$ nickel, $0.8 \%$ iron, $17 \%$ sulphur. This process took place in Canada and the matte was shipped to Britain.

(b) At the Clydach refinery the matte was first crushed and ground.

(c) This matte was calcined to produce mixed oxides of copper and nickel (calcination).

(d) The greater part of the copper was leached out with sulphuric acid (copper extraction).

$(e)$ The nickel oxide was reduced to an impure nickel powder (reduction).

$(f)$ The reduced nickel was acted upon with carbon monoxide at about $50^{\circ} \mathrm{C}$., to form a gas called nickel carbonyl (volatilization).

$(g)$ The carbonyl thus formed was heated to temperatures of about $200^{\circ} \mathrm{C}$. so that pure nickel is deposited and carbon monoxide re-formed (decomposition).

Crushing and Grinding.-The matte as received was fed at regular intervals into Krupp ball mills and ground to pass through a 60-mesh sieve, approximately 220 microns. Each calciner had its own mill and the ground matte passed continually from mill to calciner by means of conveyors, elevators, and distributors.

First Type Calciner (1900-1911).-The ground matte was subjected to a calcining process in order to convert the sulphides into oxides. It was fed into calciners, consisting of long fireproof brick tunnels 
which were heated by producer gas. The matte was agitated and moved along by means of three ploughshares fastened to a bar which was dragged through the heated matte on the calciner bed by means of a chain on either side of the plough.

Second Type of Calciner (1924).-These were of the straight line double-deck type, a preliminary roasting being carried out on the upper hearth and a finishing calcination on the lower. The matte was spread and conveyed by ploughs rotating on their own axes and circulating on endless chains. Eight ploughs were attached to each chain and the chain speed was such that it took about 12 hours for the matte to travel the whole length of the top and bottom hearths.

After calcination the original $17 \%$ sulphur in the matte was reduced to $1.5 \%$, this being present as sulphides and sulphates.

Copper Extraction.-The calcine was conveyed mechanically to Krupp ball mills, where any lumps formed in the calciners were ground through 40-mesh screens. It was then treated with $12 \%$ sulphuric acid, whereby about $75 \%$ of the copper was dissolved.

Reduction and Volatilization.-The dried copperextracted matte was conveyed to the nickel plants where the remaining operations for extracting the nickel were carried out.

On entering the plant the matte was passed through reducers in which the oxides were reduced. The reduced matte was then distributed between volatilizers, where the nickel was volatilized as carbonyl.

The volatilizers were similar in construction to the reducers, but no heating was necessary as the reaction

$$
\mathrm{Ni}+4 \mathrm{CO}=\mathrm{Ni}(\mathrm{CO})_{4}
$$

is exothermic. The matte travelled down the volatilizer where it was brought into intimate contact with an upward stream of carbon monoxide.

Decomposition.-In the decomposing apparatus the nickel carbonyl came in contact with nickel pellets heated to a temperature of about $180^{\circ} \mathrm{C}$. This caused the dissociation of the carbonyl, so that nickel was deposited on the pellets and carbon monoxide liberated.

Repetition of Extraction Processes.-The discharge still contained nickel which had not been volatilized as nickel carbonyl. It was therefore passed through the above series of operations again in order to effect further extraction.

The product of the last extracting operation was transferred to a concentrating plant, where it was successively oxidized and leached with sulphuric acid to remove the bulk of the base metals.

2
Concentrating Plant for Precious Metals.-The purpose of this was to take out copper and nickel from the concentrates, which came from the nickel sheds, in order to raise the percentage of precious metals as high as possible. The matte was calcined and sulphuric acid added to extract copper and nickel.

Period 1933-1953.-During these years, the Clydach plant and process underwent many important changes.

As the matte supplied from Canada had a high nickel and low copper content, the manufacture of copper sulphate was discontinued.

The original calciners with their individual Krupp mills were scrapped, and a large air-swept mill installed of sufficient capacity to handle all matte. Rotary hearth calciners were introduced in 1935 with conveyor feed and discharge; these effected a great improvement in calcination conditions. At the same time mechanical dust catchers and electrostatic precipitators were installed to recover dust previously carried forward to the main stacks.

The use of " soft roast sulphide" (7\% sulphur) in the process and later of " sinter" (0.5\% sulphur) has done much to improve conditions in the refinery.

In 1939 the old hand-fired water gas and producer gas producers were replaced by a modern gas plant in which the fuel is mechanically charged and most operations are automatically performed.

The substitution of high-nickel-content mattes for the original Bessemer matte increased the capacity of the nickel plants, as the extraction of nickel as carbonyl was more rapid and efficient. The number of reducers and volatilizers required for a given rate of feed was substantially reduced, and the higher concentration of nickel carbonyl in the gases from the volatilizers increased the capacity of the decomposers.

More complete and quicker extraction of nickel is achieved when the process is carried out at pressures above atmosphere. The first pressure process was started at Clydach in 1935. Much of the resulting nickel carbonyl was recovered in the liquid phase, and as such was fed into the atmospheric plants. The effect was not only to produce more pellets, but also to increase the carbon monoxide content of the volatilizer gases, and so improve the degree of extraction.

Period 1953 to Date.-The only fundamental change in process operations since 1953 has been the installation of the direct wet treatment plant, and the closing down of the Orford furnace.

Instead of smelting concentrate 2, discharged from the nickel plant, in the Orford furnace, this material is now calcined at a low temperature, and leached 
first with water and then with dilute sulphuric acid. The residue is dried and smelted. By these means some $20 \%$ of the nickel, $65 \%$ of the cobalt, and $80 \%$ of the copper are recovered before smelting.

The smelt matte is crushed, ground, calcined, and fed to the old wet treatment plant for extraction of the base metals and preparation of precious metal concentrate.

All copper, coming into the works in the raw sinter, is now converted to copper sulphate for sale.

\section{Statistical Investigations}

After the carbonyl process had been in operation for about 30 years, several deaths from respiratory cancer occurred and Professor Bradford Hill was approached with a view to obtaining statistical information relating to the incidence of carcinoma of the respiratory system at the works. Bradford Hill found that not only was there an apparently abnormal incidence of carcinoma of the lung and nose in the refinery population from 1929 to 1938 , but that this excess was confined to the process workers. An abstract of Bradford Hill's report of October, 1939, is as follows:-

(1) The numbers and ages of the workmen employed at the refinery and of pensioners on the books were available for two dates, namely April 28, 1931, and June 30, 1937. The age distribution did not vary appreciably between these dates and the mean of the two figures may therefore be taken as a reasonable representation of the population over the nine years of the inquiry 1929-1938. Annual figures for the population of all ages for these years give an average of 950 men. This figure, with the age distribution shown in Table 1 , has been taken as the population exposed to risk of dying between 1929 and 1938.

(2) To this population was applied the age specific death rates of men in all England and Wales in the quinquennium 1931-35 for (a) all causes of death, (b) cancer of all sites, and (c) respiratory cancer. The

TABLE 1

CALCUlation OF POPULATION AT RISK: 1929 TO 1938

\begin{tabular}{|c|c|c|c|c|c|c|}
\hline \multirow[t]{2}{*}{ Age } & \multicolumn{2}{|c|}{$\begin{array}{l}\text { No. of Work- } \\
\text { men and } \\
\text { Pensioners }\end{array}$} & \multicolumn{2}{|c|}{ Distribution } & \multirow{2}{*}{$\begin{array}{c}\text { Mean \% } \\
1931 \\
\text { and } \\
1937\end{array}$} & \multirow{2}{*}{$\begin{array}{c}\text { Distribution } \\
\text { of } \\
\text { Population } \\
\text { of } 950\end{array}$} \\
\hline & 1931 & 1937 & 1931 & 1937 & & \\
\hline $\begin{array}{c}15- \\
20- \\
25- \\
35- \\
45- \\
55- \\
65- \\
75-85\end{array}$ & $\begin{array}{r}13 \\
23 \\
205 \\
251 \\
230 \\
95 \\
16 \\
5\end{array}$ & $\begin{array}{r}36 \\
78 \\
234 \\
292 \\
230 \\
154 \\
25 \\
4\end{array}$ & $\begin{array}{r}1.55 \\
2.74 \\
24.47 \\
29.96 \\
27.44 \\
11.34 \\
1.91 \\
0.60\end{array}$ & $\begin{array}{r}3.42 \\
7.41 \\
22 \cdot 22 \\
27.73 \\
21 \cdot 85 \\
14.62 \\
2.37 \\
0.39\end{array}$ & \begin{tabular}{r|}
2.49 \\
5.08 \\
23.35 \\
28.85 \\
24.65 \\
12.98 \\
2.14 \\
0.50
\end{tabular} & $\begin{array}{r}24 \\
48 \\
222 \\
274 \\
234 \\
123 \\
20 \\
5\end{array}$ \\
\hline All ages & 838 & 1,053 & $100 \cdot 01$ & $100 \cdot 01$ & $100 \cdot 04$ & 950 \\
\hline
\end{tabular}

TABLE 2

COMPARISON OF DEATHS EXPECTED AT RATES FOR MEN IN ALL ENGLAND AND WALES AND DEATHS OBSERVED IN REFINERY POPULATION

\begin{tabular}{|c|c|c|}
\hline & $\begin{array}{c}\text { Estimated Expected } \\
\text { Deaths in 88 Years } \\
(1929-1938)\end{array}$ & $\begin{array}{c}\text { Observed } \\
\text { Deaths } \\
\text { in Same } \\
\text { Period }\end{array}$ \\
\hline 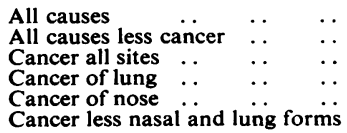 & $\begin{array}{r}84 \\
72 \\
12 \\
1 \\
0-1 \\
10-11\end{array}$ & $\begin{array}{r}105 \\
67 \\
38 \\
16 \\
11 \\
11\end{array}$ \\
\hline
\end{tabular}

"expected" deaths on this basis are compared in Table 2 with those actually observed.

(3) The results show that there were 105 observed deaths from all causes (excluding three deaths of office staff) and 84 expected at the national rates. Sub-division of these deaths by cause gives a very striking picture. From all causes less cancer, 72 deaths were expected and 67 were observed, only a very small difference. But from cancer as a whole 12 deaths only were expected and as many as 38 were observed, a very heavy excess.

This excess of cancer mortality lies entirely in two sites. From cancer of the lung only one death would be expected at the recorded rates for England and Wales; 16 were observed. Of nasal cancers, 11 were observed and, in the absence of national figures, certainly not more than one would be expected.

If these cancers of the lung and nose are excluded about 10 deaths from cancer of other sites would be expected; actually 11 were observed, a remarkably close concordance.

(4) The abnormal incidence of cancer of two sites can be further and informatively analysed. The population of the refinery can be broadly divided into two groups, the process and the non-process workers, the former including all the processes and the latter the workers in the power house, on plant repairs, electrical, mechanical, traffic, yard, superintendence, and general. The average numbers of each over the years in question were 438 process

TABLE 3

COMPARISON OF DEATHS IN PROCESS AND NON-PROCESS WORKERS

\begin{tabular}{l|c|c}
\hline & \multicolumn{2}{|c}{$\begin{array}{c}\text { No. of Deaths Recorded } \\
\text { (June, 1929-January, 1938) }\end{array}$} \\
\cline { 2 - 3 } & Process Workers & Other Workers \\
\hline $\begin{array}{l}\text { Respiratory causes } \\
\text { Heart disease and cerebral } \\
\text { haemorrhage }\end{array}$ & 13 & 10 \\
Other causes (except cancer) & 75 & 17 \\
Total less cancer & 35 & 7 \\
Cancer: Nasal & 11 & 34 \\
Lung & 15 & 1 \\
Other sites & 7 & 5 \\
Total cancer atal all causes & 33 & 6 \\
\hline
\end{tabular}


workers and 389 non-process workers. There were also rather more pensioners who had been process workers. In total, therefore, this group was rather larger and older than the group of non-process workers (the actual age distributions were unknown) and might be expected to suffer a slightly higher mortality. The deaths actually observed in each group are set out in Table 3 . It will be seen that from 1929 to 1938 there were 108 deaths in all (including three deaths of office staff not included in Table 2).

From causes other than cancer there were 35 deaths of process workers and 34 of other workers, a position which perhaps rather favours the process workers if they are slightly the larger and older group.

From cancer of all sites there were 33 deaths of process workers and only six of other workers.

There is no material difference between the two groups in any broad cause group except cancer, and the excess here relates entirely to cancer of the two sites, nose and lung. Other forms of cancer are approximately equal (seven deaths amongst process workers, five amongst other workers).

(5) In short, not only does there appear to have been an abnormal incidence of cancer of the lung in the refinery population as a whole in 1929-1938, but it seems that this abnormality has been practically, probably entirely, confined to the process workers.

Carcinoma of the lung and nose in workers who were occupied in a factory where nickel is produced by decomposition of a gaseous nickel compound were included in the list of prescribed diseases in 1949.

It was thought that further investigation was necesa certain period were not affected. In order to carry out this investigation, a register of all new employees was prepared.

This register (Appendix I) shows that between 1900 and 1957 there were 9,340 new entrants, and of these $131(1.4 \%)$ developed cancer of the lung, and $61(0.65 \%)$ developed cancer of the nose.

The minimum duration of service for a known case was one and a quarter years for carcinoma of the lung and six years for carcinoma of the nose. A sary as it seemed that those entering the works after

truer picture of incidence is therefore given by excluding those new entrants who remained in employment less than one year. Between 1900 and 1929 there were 2,094 entrants who remained over one year; $131(6.3 \%)$ of these developed cancer of the lung and $61(2.9 \%)$ developed cancer of the nose.

From Appendix $I$ it is evident that the incidence varied from year to year, and it was thought pertinent to enquire how this variation affected different groups of entrants.

The percentage of entrants, excluding those who remained in employment less than one year, who developed cancer of the lung or nose was therefore calculated. The results are given in Table 4 and Fig. 1.

The highest incidence of cancer of the lung and nose occurred in those workers who began work between 1905 and 1914 . Owing to the very long lag period between exposure and development of cancer, there are probably a few deaths still to occur. There was a progressive fall until 1920, when the incidence rose, but fell again after 1924 (Appendix I). The lung cases were more numerous than the nose cases.

No cases of cancer of the nose and only six cases of cancer of the lung have been recorded in persons who entered the works for the first time after 1924. The expected number of cancer of the lung cases since 1924, calculated at the England and Wales rate for the various age groups, was four.

Fig. 2 shows the actual number of carcinoma cases, both nose and lung, according to year of entry.

In Appendix II an analysis is given of the occupations of men who were known to have suffered from nickel carbonyl poisoning and who later developed cancer of the lung or nose. The detailed occupations of those who entered in 1922-24 and who later developed cancer of the lung or nose are also given.

General data on the occurrence of cancer of the lung and nose are as follows:-

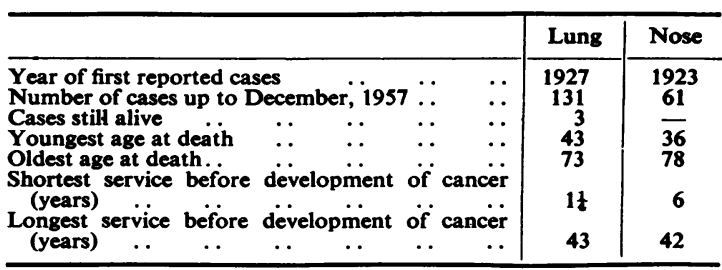

TABLE 4

PERCENTAGE OF ENTRANTS WITH MORE THAN ONE YEAR'S SERVICE LATER DEVELOPING CARCINOMA OF LUNG OR NOSE

\begin{tabular}{|c|c|c|c|c|c|c|c|c|}
\hline $\begin{array}{c}\text { Year } \\
\text { of } \\
\text { Entry }\end{array}$ & $\begin{array}{c}\text { Carcinoma } \\
\text { of Lung } \\
(\%)\end{array}$ & $\begin{array}{c}\text { Carcinoma } \\
\text { of Nose } \\
(\%)\end{array}$ & $\begin{array}{l}\text { Year } \\
\text { of } \\
\text { Entry }\end{array}$ & $\begin{array}{l}\text { Carcinoma } \\
\text { of Lung } \\
(\%)\end{array}$ & $\begin{array}{c}\text { Carcinoma } \\
\text { of Nose } \\
(\%)\end{array}$ & $\begin{array}{c}\text { Year } \\
\text { of } \\
\text { Entry }\end{array}$ & $\begin{array}{l}\text { Carcinoma } \\
\text { of Lung } \\
(\%)\end{array}$ & $\begin{array}{c}\text { Carcinoma } \\
\text { of Nose } \\
(\%)\end{array}$ \\
\hline $\begin{array}{l}1900- \\
1905- \\
1910- \\
1915-\end{array}$ & $\begin{array}{r}15.1 \\
15.8 \\
13.0 \\
1.7\end{array}$ & $\begin{array}{r}1.9 \\
9.6 \\
10.8 \\
0.9\end{array}$ & $\begin{array}{l}1920- \\
1925- \\
1930- \\
1935-\end{array}$ & $\begin{array}{l}6.6 \\
0.9 \\
0.4 \\
-\end{array}$ & $\begin{array}{l}1 \cdot 3 \\
=\end{array}$ & $\begin{array}{l}1940- \\
1945- \\
1950- \\
1955\end{array}$ & $\begin{array}{l}0.6 \\
0.1 \\
-\end{array}$ & 二 \\
\hline
\end{tabular}




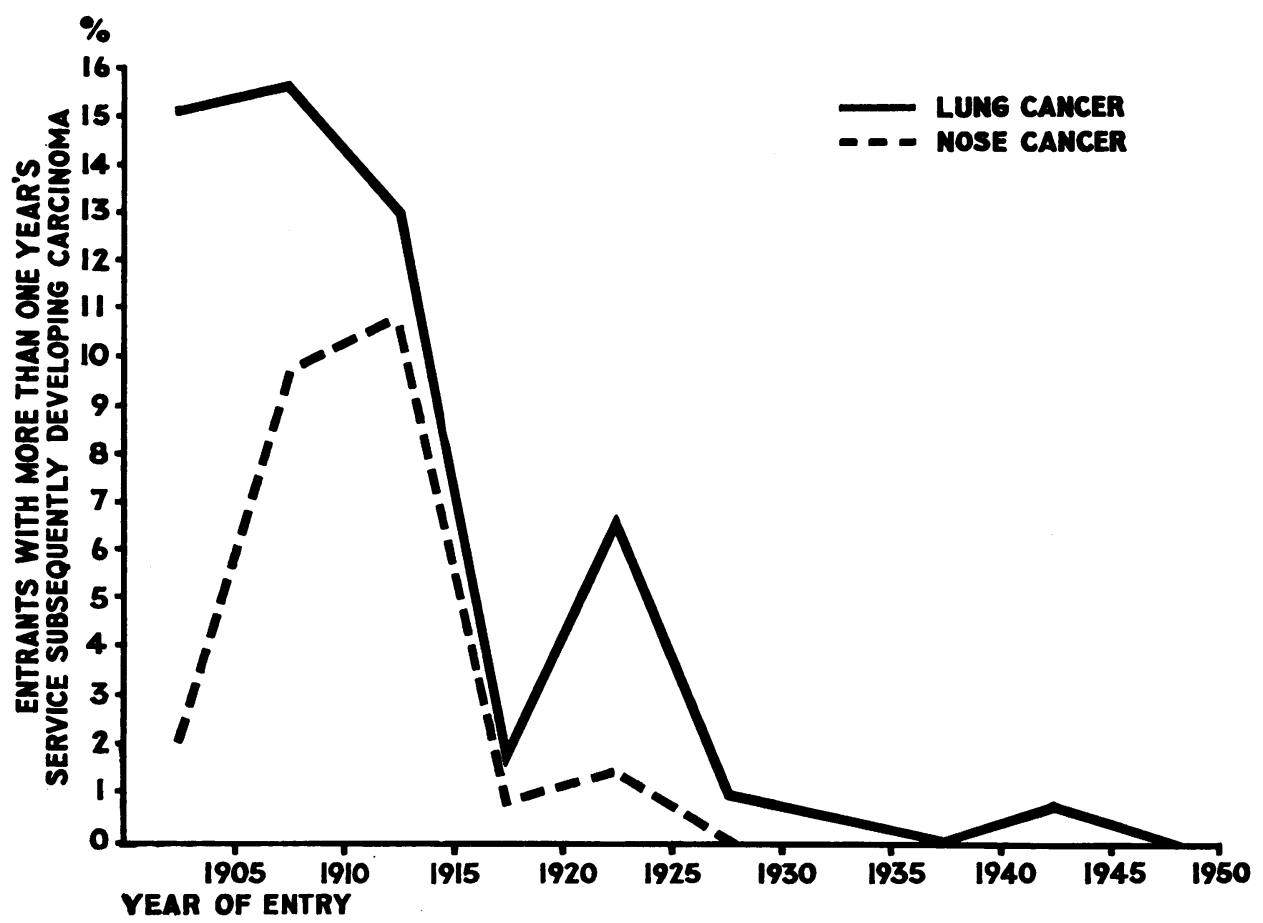

FIG. 1.-The incidence of carcinoma of the lung and nose according to year of entry in entrants with more than one year of service.

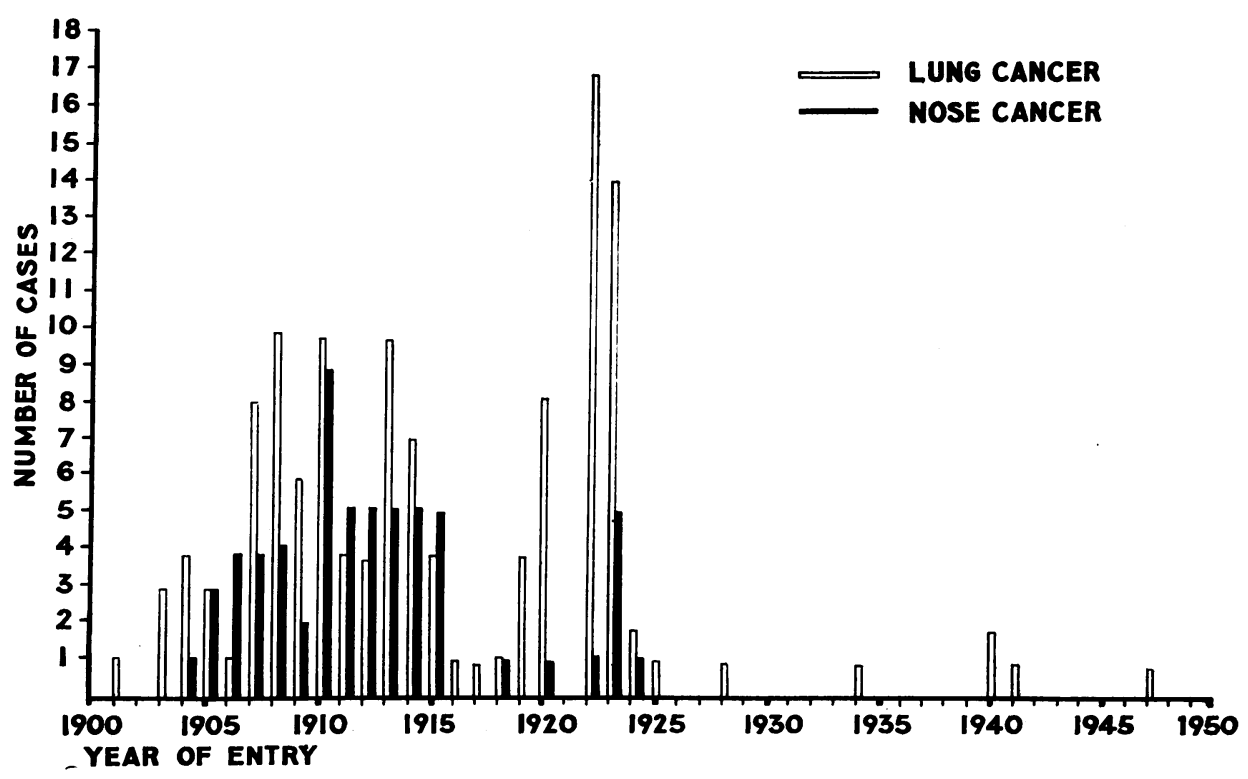

Fig. 2.-Number of cases of carcinoma of lung and nose according to year of entry. 
The occurrence of cancer of the lung and nose in nickel workers is likely to be affected by the following factors:- (a) Length of service and "lag" period; (b) occupations followed; (c) materials involved; $(d)$ preventive measures.

(a) Length of Service.-It has long been realized that a considerable time elapses between the exposure of an individual to risk and the occurrence of industrial cancer. This interval, for convenience called the "lag" period, may be as long as 25 years and perhaps even longer. It is this factor which accounts for the deaths that have occurred at Clydach in recent years.

The "lag" period is influenced by several factors such as age at entry into the occupation, length of service, variations in concentrations of carcinogen, and individual susceptibility.

In practice difficulty was experienced in establishing the exposure period in many cases. The term " labouring" appears in most men's history, and at first this occupation was not considered hazardous, but further investigation showed that labourers might be called upon to work in any part of the plant. Again, the date of onset of the disease was sometimes difficult to establish with certainty. The length of service from entry to the works until death was therefore recorded. The results are given in Table 5 and Fig. 3.

It is interesting to note that the time from first
TABLE 5

NUMBER OF YEARS BETWEEN ENTRY TO WORKS AND DEATH (ALL CASES DYING UP TO DECEMBER 31, 1957, DEATH (ALL CASES DYING UP TO

\begin{tabular}{|c|c|c|}
\hline \multirow{2}{*}{$\begin{array}{l}\text { No. } \\
\text { of Years' } \\
\text { Service }\end{array}$} & Cancer of Lung & Cancer of Nose \\
\hline & No. of Deaths & No. of Deaths \\
\hline \multirow[t]{2}{*}{$\begin{array}{l}0- \\
5- \\
10- \\
15- \\
20- \\
25- \\
30- \\
35- \\
40-\end{array}$} & $\begin{array}{rc}6 & (4.6 \%) \\
3 & (2.3 \%) \\
3 & (2.3 \%) \\
11 & (8.4 \%) \\
27 & (20.6 \%) \\
31 & (23.6 \%) \\
25 & (19.1 \%) \\
16 & (12.2 \%) \\
9 & (6.9 \%)\end{array}$ & $\begin{array}{rr} & (6.5 \%) \\
4 & (8.1 \%) \\
5 & (14.7 \%) \\
9 & (39.2 \%) \\
23 & (18.0 \%) \\
11 & (9.6 \%) \\
6 & (3.2 \%) \\
2 & (1.6 \%)\end{array}$ \\
\hline & $131(100 \cdot 0 \%)$ & $61(100.9 \%)$ \\
\hline \multicolumn{2}{|c|}{$\begin{array}{l}\text { Mean } 26.9 \\
\text { S.D. } \pm 6.15\end{array}$} & $\begin{array}{l}\text { Mean 22.65 } \\
\text { S.D. } \pm 7.0\end{array}$ \\
\hline
\end{tabular}

exposure to death is similar to the time lag of bladder cancer in certain chemical workers, of lung cancer in chrome workers, and in miners at Schneeberg.

(b) Occupations Followed.-Table 6 gives the number of patients who worked at a single job at Clydach during the period 15 to 25 years before death, and Table 7 the patients who worked at more than one job. These tables suggest that the occupations meriting special attention are calcination, the production of copper sulphate and nickel sulphate, and furnace work.

Table 6 indicates that the majority of both lung and nose cancers occurred in those engaged in what were formerly dusty processes. The highest

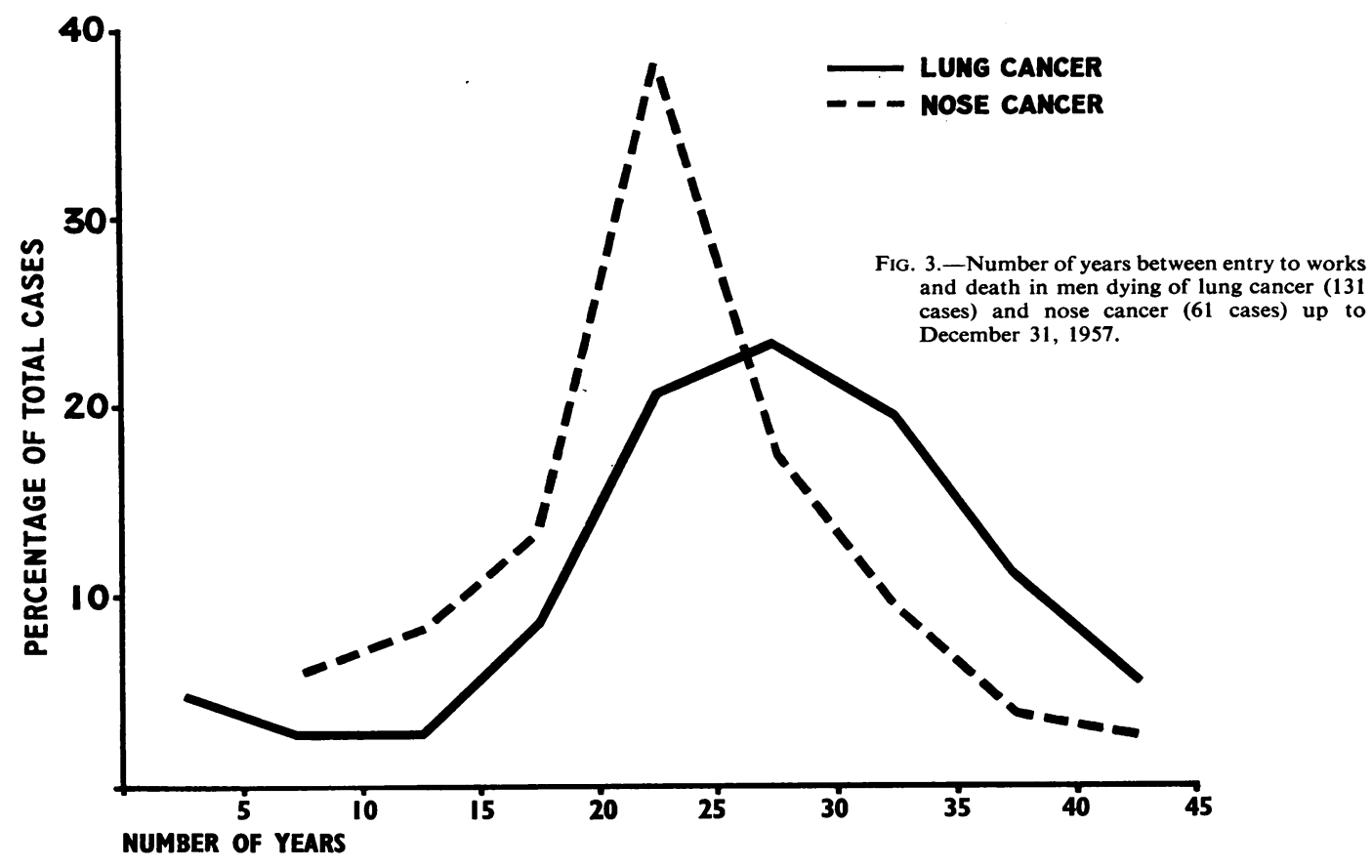


TABLE 6

OCCUPATIONAL INCIDENCE IN VARIOUS PROCESSES IN MEN WORKING IN ONE DEPARTMENT ONLY DURING

\begin{tabular}{l|c|c|c}
\multicolumn{3}{c}{15 TO 25 YEARS BEFORE DEATH } \\
\hline $\begin{array}{c}\text { Process or } \\
\text { Department }\end{array}$ & $\begin{array}{c}\text { Average } \\
\text { Annual } \\
\text { Population }\end{array}$ & $\begin{array}{c}\text { No. of Cases } \\
\text { of Carcinoma } \\
\text { of Lung }\end{array}$ & $\begin{array}{c}\text { No. of Cases } \\
\text { of Carcinoma } \\
\text { of Nose }\end{array}$ \\
\hline Gas producers & -58 & 1 & -14 \\
Calcination & 57 & 20 & 8 \\
Copper sulphate & 87 & 4 & 3 \\
Nickel sulphate & 57 & 2 & 5 \\
Furnaces & 36 & 2 & 1 \\
Concentrate & 26 & 5 & 1 \\
Nickel sheds & 163 & 9 & 1 \\
\hline Fitters & 80 & 57 & 33 \\
\hline Totals .. & 507 & &
\end{tabular}

TABLE 7

MEN WORKING IN MORE THAN ONE DEPARTMENT DURING 15 TO 25 YEARS BEFORE DEATH

\begin{tabular}{|c|c|c|}
\hline Department & $\begin{array}{l}\text { No. of Cases } \\
\text { of Carcinoma } \\
\text { of Lung }\end{array}$ & $\begin{array}{l}\text { No. of Cases } \\
\text { of Carcinoma } \\
\text { of Nose }\end{array}$ \\
\hline $\begin{aligned} & \text { Calciners }+ \text { nickel sheds } \\
&+ \text { copper sheds } \\
&+ \text { nickel sulphate } \\
&+ \text { furnaces } \\
& \text { Copper sheds + nickel sulphate } \text { + furnaces } \\
& \text { Nickel sheds }+ \text { copper sheds } \\
&+ \text { furnaces } \\
& \text { Non-process workers } \\
& \text { Miscellaneous + furnaces } \\
& \text { Gas producers } \\
& \text { + copper sheds }\end{aligned}$ & $\begin{array}{r}4 \\
7 \\
1 \\
1 \\
4 \\
1 \\
9 \\
2 \\
7 \\
36 \\
1 \\
1\end{array}$ & $\begin{array}{l}\frac{1}{\frac{9}{4}} \\
\frac{3}{3} \\
\frac{11}{2}\end{array}$ \\
\hline Totals .. $\quad . . \quad \ldots$ & 74 & 28 \\
\hline
\end{tabular}

frequencies were in the calciners, copper sulphate plant workers, furnace workers, crushing and grinding department workers, and in those transporting matte from the calciners to the nickel sheds.

The dust in the calcination department was of a very fine and pyrophoric nature. In the copper sheds there was a fine copper sulphate powder which had a local corrosive effect; it also contained certain arsenical compounds.

(c) Materials Involved.-Much has been written to indicate the nature, number, and great variety of the chemical carcinogens. Those that might have been present in Clydach are: (i) Radioactive substances, (ii) arsenic, and (iii) nickel carbonyl.

(i) Radioactive Substances.-Tests carried out by means of a sensitive electroscope at the works and also by photographic, electroscopic, and emanation methods in the laboratory yielded no evidence of radioactivity of the nickel matte at any stage in the process.

(ii) Arsenic.-Arsenic was present both in the matte and in the sulphuric acid used for extraction of copper sulphate. Before 1921 the sulphur smelt matte contained a considerable quantity of arsenic derived from sulphuric acid which had been used for the extraction of copper. The arsenic remained in the matte throughout the process until it came to the melting furnaces and calciners as a copper-nickel arsenite. A record was maintained of the amount of arsenic present in the sulphuric acid used up to 1927 , and is presented in Table 8.

TABLE 8

AMOUNTS OF ARSENIC IN SULPHURIC ACID

\begin{tabular}{|c|c|c|c|c|c|c|c|}
\hline Year & $\begin{array}{c}\text { Amount } \\
\text { of } \\
\text { Arsenic } \\
\text { (tons) }\end{array}$ & Year & $\begin{array}{c}\text { Amount } \\
\text { of } \\
\text { Arsenic } \\
\text { (tons) }\end{array}$ & Year & $\begin{array}{c}\begin{array}{c}\text { Amount } \\
\text { of } \\
\text { Arsenic } \\
\text { (tons) }\end{array} \\
\text { (a) }\end{array}$ & Year & $\begin{array}{c}\text { Amount } \\
\text { of } \\
\text { Arsenic } \\
\text { (tons) }\end{array}$ \\
\hline $\begin{array}{l}1903 \\
1904 \\
1905 \\
1906 \\
1907 \\
1908 \\
1909\end{array}$ & $\begin{array}{r}3.0 \\
6.7 \\
7.2 \\
12.2 \\
18.4 \\
25.6 \\
22.0\end{array}$ & $\begin{array}{l}1910 \\
1911 \\
1912 \\
1913 \\
1914 \\
1915 \\
-\end{array}$ & $\begin{array}{c}27 \cdot 0 \\
30 \cdot 0 \\
34 \cdot 0 \\
40 \cdot 0 \\
50 \cdot 0 \\
60 \cdot 0 \\
-\end{array}$ & $\begin{array}{l}1916 \\
1917 \\
1918 \\
1919 \\
1920 \\
1921 \\
-\end{array}$ & $\begin{array}{r}68.8 \\
102.5 \\
89.5 \\
108.7 \\
13.6 \\
9.4 \\
-\end{array}$ & $\begin{array}{l}1922 \\
1923 \\
1924 \\
1925 \\
1926 \\
1927\end{array}$ & $\begin{array}{l}1 \cdot 1 \\
0.63 \\
0.64 \\
0.35 \\
0.25 \\
\text { Nil } \\
-\end{array}$ \\
\hline
\end{tabular}

From 1921 onwards the quantity of arsenic contained in the acid fell, but it was not until 1924 that all the old stock of acid was used. Since 1926 the acid used has been practically free of arsenic.

Amor (1939) found that slight cases of arsenic poisoning did occur in nickel workers, together with characteristic skin rashes and oedema of the scrotum. From an examination of sickness records before 1934 he noted that several cases of cholaemia were reported and that after 1920 they almost completely ceased; the relationship of this to arsenic poisoning, if any, is unknown.

(iii) Nickel Carbonyl.-The suggestion that respiratory cancer is in some way linked with nickel carbonyl is not supported for the following reasons:

(1) There has been no material change in the process in the nickel sheds where nickel carbonyl gas has been produced over the last 50 years, to which could be attributed the improvement in the incidence of respiratory cancer which has occurred since 1925.

(2) In the nickel sheds, in addition to the carbonyl hazard, there was also a dust hazard where the matte was brought in and discharged from the plant. Before 1925 the sulphuric acid used contained considerable amounts of arsenic. No case of carcinoma of the nose has occurred in men who entered the works after 1924 and the incidence of cancer of the lung in these men is not above the national average.

(3) Of 131 lung and 61 nose carcinoma cases, only 15 had suffered from the effects of nickel carbonyl inhalation, and of these 10 were lung cases and five were nose cases. Most of these cases had been engaged in various occupations in the works. In five of the cases, gassing occurred less than four years before death.

(4) Løken (1950) has reported carcinoma of the lung in a Norwegian works where nickel is refined other than by the carbonyl process.

(d) Preventive Measures. - As a result of the suggestion that arsenic might be the carcinogenic agent 
responsible for the high incidence of respiratory cancer, measures were taken to exclude metallic arsenides from the process, to provide arsenic-free sulphuric acid, and to suppress dust at every stage of the process. Details of the various improvements made are given below:-

In 1910, a plough type of calciner, which operated from 1902 to 1911 , was changed to double-deckers with rotary rakes which, although very dusty, were an improvement on the first type.

In 1922, arsenic-free sulphuric acid was used. Nose and mouth respirator pads were issued.

In 1924, calciners were shortened and improved.

In 1929, the copper sulphate plant was closed down.

In 1934, the mattes were changed and now contained only $2 \%$ copper instead of $35 \%$, and only $2 \%$ sulphur instead of $20 \%$.

In 1935, Lodge Cottrell electrostatic precipitators diminished the amount of dust emitted from the stacks. Also from that date the whole of the crushing and grinding of the material is now done in a central grinding plant which is virtually dust free. Formerly the crushing and grinding was done separately in each plant by means of Krupp crushers, which were very dusty.

In 1936, new calciners were installed. The old type led to underground flues which had to be cleaned very frequently, and it is significant that most of the nose cases occurred amongst the men who were engaged in cleaning these flues. The new calciners are in a well-ventilated room and the flue gasses from these calciners are taken to two Lodge Cottrell electrostatic precipitators.

In 1937, a new type of closed bogie was used instead of the open trucks, which has an automatic emptying device fitted to it with a new suction feed apparatus which makes it possible to feed this matte into the nickel sheds without making the slightest dust if used properly. Also new feed elevators were introduced to the nickel sheds.

In 1944, the matte was free from sulphur.

\section{Medical Control}

Comprehensive pre-employment medical examinations, including a chest radiograph, are now carried out. Routine examinations are undertaken annually and particular attention is paid to any possible manifestation of industrial disease; the annual re-examination includes a chest radiograph. All employees are medically examined before return to work if they have been absent on sick leave for more than one month. Regular dust counts are undertaken in all dusty processes; the plant superintendents are given the results of these tests and they are encouraged to keep the counts at a low level.

\section{Summary}

(1) At Clydach Works, the incidence of cancer of the lung and nose among workers engaged in the refining of nickel and the preparation of nickel and copper salts was found to be greater than that of the general population. One hundred and thirtyone cases of lung cancer and 61 of cancer of the nose are reported. A description is given of the nickel carbonyl process.

(2) The increased incidence of cancer of the lung and nose, which has not been noted amongst workers engaged in processes involving the use of metallic nickel, appeared to be related to: (a) Dusty occupations rather than to occupations where nickel is dealt with as a gaseous compound, and/or (b) drying and powdering of copper sulphate, and/or (c) the sulphuric acid used before 1921 which was far from pure and contained arsenic.

(3) As an index of the action of any carcinogenic material which had been present at the Clydach Works, the incidence of nasal cancer was far more significant than that of lung cancer. No deaths from nasal cancer have been recorded from workers engaged after 1924, at which date increased precautions were taken against dust.

(4) It is considered that dust, possibly the heated calcined dusts, contained the carcinogen. Before 1924 this dust probably contained arsenic from the sulphuric acid used. After taking into account (i) the period of exposure to the hazard (minimum one year); (ii) the long lag period between exposure and the appearance of the first signs and symptoms; and (iii) the survival period after diagnosis (on the average between 18 and 24 months), it is not unreasonable to draw the inference that carcinogenic material may possibly have been present in the heated calcined dusts-possibly in their arsenic content.

(5) The average period from entry to the works to death was 27 years in lung cancer cases and 22 years in nose cancer cases.

(6) Deaths from carcinoma of the lung and nose which occurred in men not employed in the calcination process may be attributable to the fact that they came into contact with calcined dusts during the course of their employment.

It is a pleasure to express my grateful thanks to my staff for their great help in the preparation of this paper.

\section{REFERENCES}

Amor, A. J. (1939). Bericht über den VIII. internationalen Kongress für Unfallmedizin und Berufskrankheiten, Frankfurt A.M., für Unfallmedizin und Berufskrankhei

Bradford Hill, A. (1939). Report to Mond Nickel Company.

Løken, A. C.'(1950). T. norske Laegeforen, 70, 376. 


\section{APPENDIX I}

\section{Register of Employees}

A register was prepared of the new entrants each year; no re-engaged person was included. The following particulars were recorded in the register:-

(1) The number of entrants.

(2) The number employed annually, i.e. the establishment.

(3) Numbers employed by years-of-service groups: under one year, one-10 years, 11-20 years, and those who remained over 20 years.

(4) Number of cases of carcinoma of the lung and nose.

(5) Percentage of the entrants who developed (a) carcinoma of the lung, $(b)$ carcinoma of the nose.

(6) The number of deaths due to other causes.

Table 9 gives the figures obtained from this register.
In calculating the percentages of new entrants who developed carcinoma of the lung or nose, those with less than one year's service have been omitted, as the minimum duration of service for a known case was one and a quarter years for carcinoma of the lung and six years for carcinoma of the nose.

The total number of new entrants from 1900 to December 31, 1957, was 9,340. The Company has a pension scheme which enables it to keep records of all pensioners, wherever they may live; they are visited annually and thus the Company is able to keep in touch with them. When pensioners die a death certificate must be furnished in order that their dependants may obtain a death benefit and the cause of death is, therefore, recorded in every case.

The labour turnover is equal to the average for the area and only a few men change their employment and leave the district. A scrutiny of the local death register

TABLE 9

CASES OF CARCINOMA OF LUNG AND NOSE BY YEARS-OF-SERVICE GROUPS AND EXPRESSED AS A PERCENTAGE OF ENTRANTS WITH MORE THAN ONE YEAR'S SERVICE

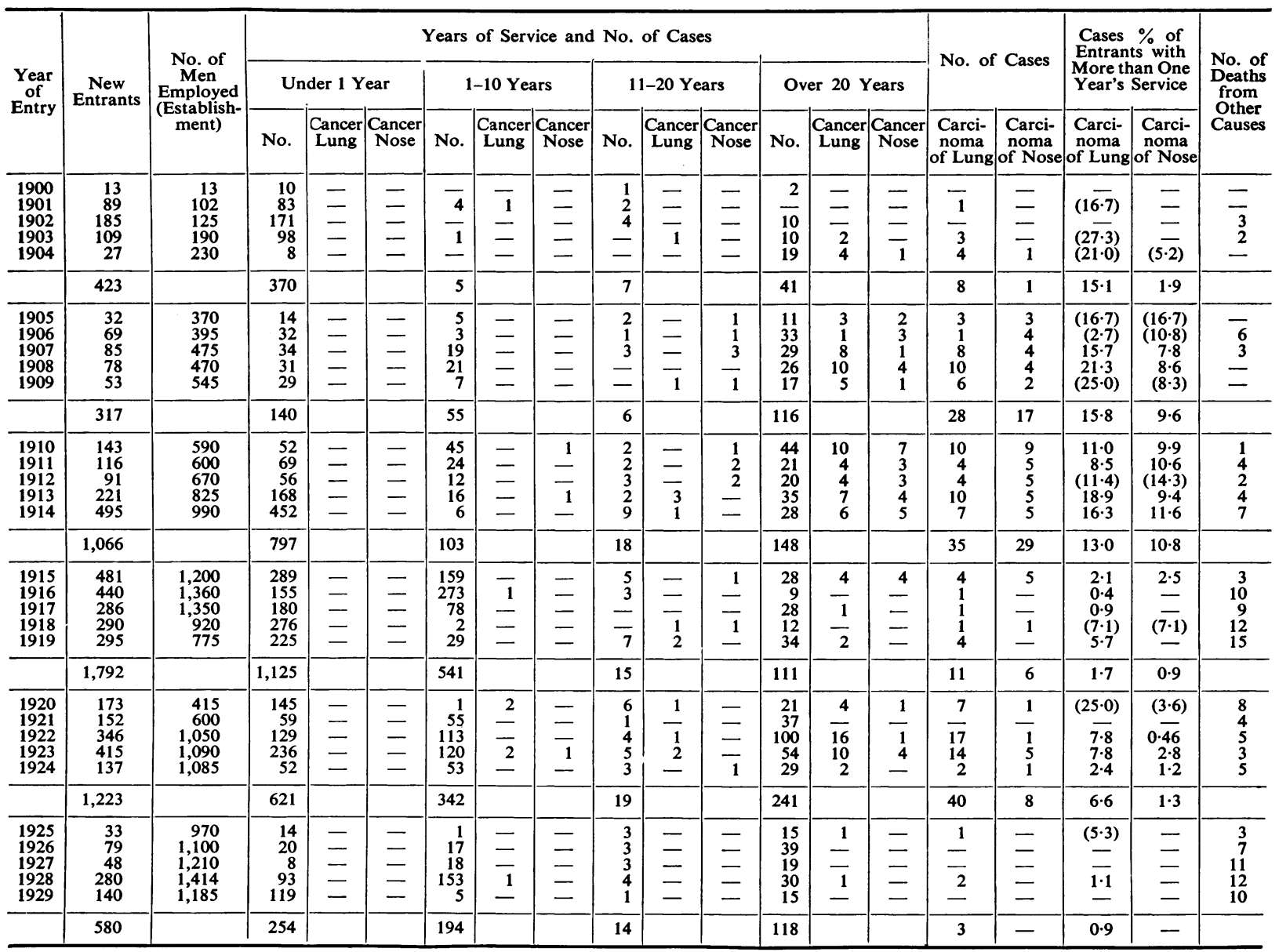



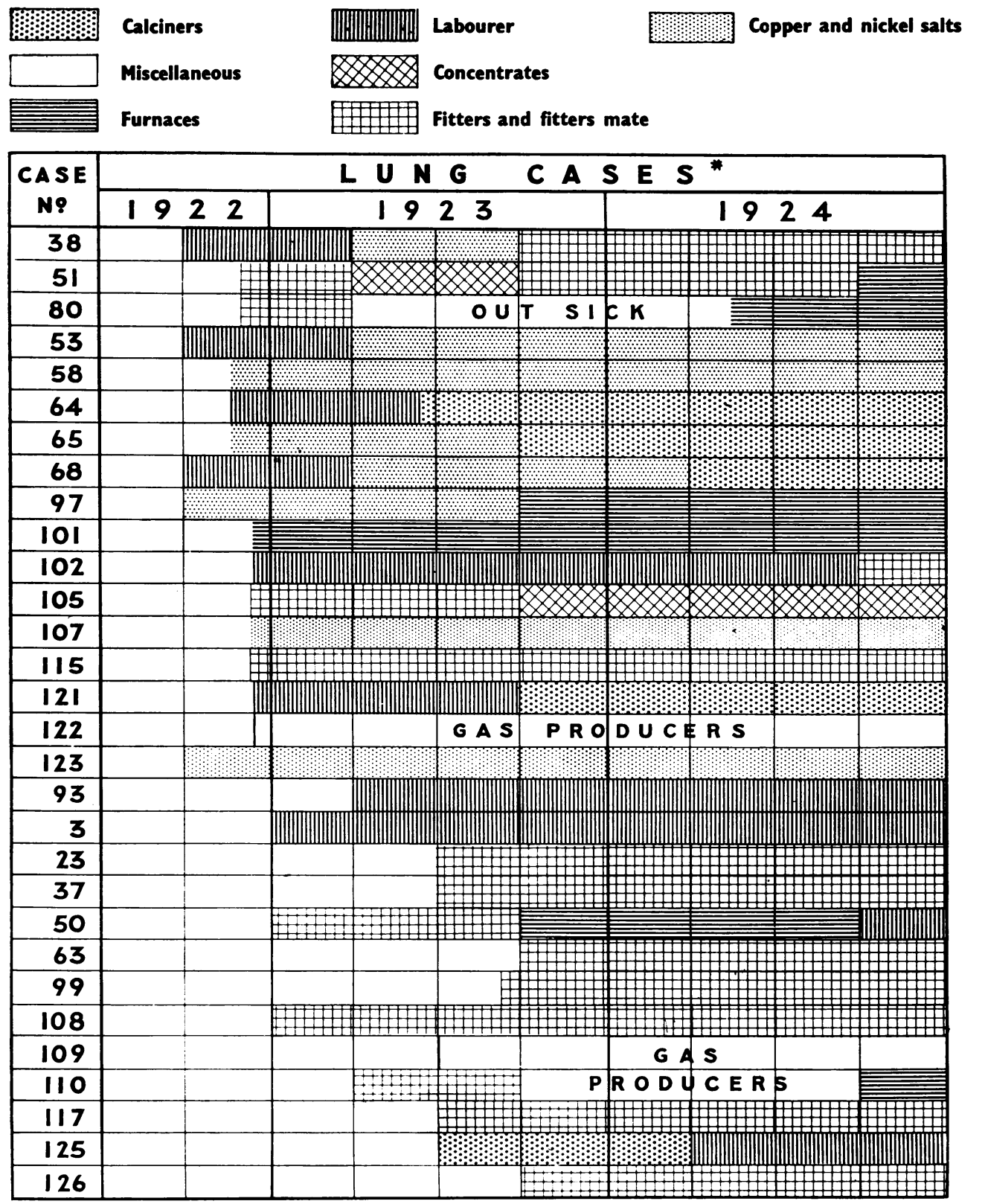

NOSE CASES

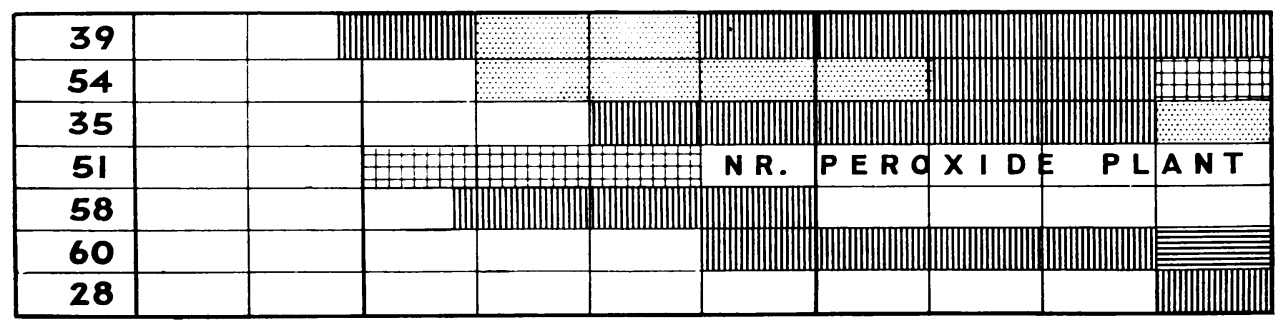

FIG. 4.-Occupations of those who entered the industry in 1922, 1923, and 1924 and later developed carcinoma of the lung or nose.

*The detailed occupations of three lung cases could not be traced. 
has yielded a few names in addition to those of pensioners. Two additional cases were thus discovered by W. R. S. Doll (personal communication), during his investigation of death certificates for nasal cancer, but one of these men had had only one year's service with the Company.

\section{APPENDIX II}

ANALYSIS OF OCCUPATIONS OF CASES OF CARCINOMA OF LUNG AND NOSE KNOWN TO HAVE SUFFERED FROM NICKEL CARBONYL POISONING

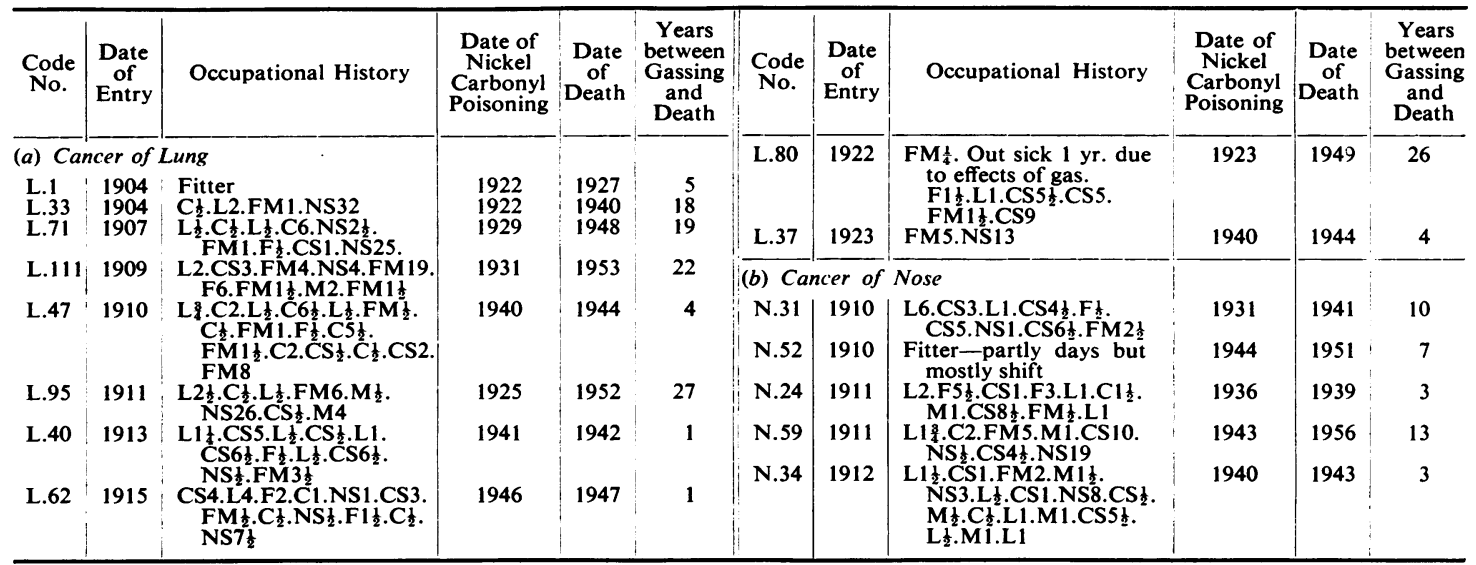

$\mathrm{C}=$ Calciners; $\mathrm{CS}=\mathrm{Nickel}$ sulphate and copper sulphate; $\mathrm{NS}=\mathrm{Ni}$ sheds; $\mathrm{L}=\mathrm{Labourer} ; \mathrm{M}=\mathrm{Miscellaneous} ; \mathrm{F}=\mathrm{Furnaces}$; FM = Fitter's mate. (Figures denote years or part years.)

There were 10 men with lung cancer and five with nose cancer who had at some time actually suffered from nickel carbonyl poisoning. If the occupational histories of these cases are closely scrutinized it will be seen that only four were mostly engaged in nickel sheds, whilst the others had a varied occupational history. 